\title{
Becoming Art: Life-works of Tehching Hsieh in Deleuzian Perspective
}

\section{Jan Suk}

The figure of Tehching Hsieh stands out in the context of western performance art as a solitary figure. His works, sometimes attributed to as "lifeworks" (Heathfield), create a unique example the confluence of artist's life and work, in other words, almost an unparalleled work that encapsulates almost the whole duration of the artist's life and stands out of cultural boundaries. The analysis accentuates the aspects of performativity and identity in the works of Hsieh using Deleuze and Guattari's concept of deterritorialization, and becoming as the vehicle to highlight the dissolving of authorian identity into their work and blurring artist's life with their work.

This paper applies the terminological framework of Deleuze and Guattati onto the work of Tehching Hsieh. Besides the aforementioned deterritorialzation and becoming, the paper further elaborates on the notion of haecceity, most notably on its "thisness" phenomenon - so symptomatic for performance art as a creative strategy. Conclusions are drawn on the basis that Deleuzian reading of performance art scrutinizes sufficiently the utmost complex, rhizomatic character of the seemingly dichotomy - the issue of blurring art+life.

\section{Becoming Art: Life-works of Tehching Hsieh in Deleuzian Perspective}

I don't think that art can change the world. But at least art can help us to unveil life. Hsieh ${ }^{1}$

\section{Memoirs of a Deleuze Reader}

Ideas do not die.

Deleuze $^{2}$ 


\subsection{Rhizome}

To approach the complexity of Deleuzean philosophy, one should not isolate phenomena of his thought; on the contrary the work of Deleuze is highly interconnected, or to use the term rhizomatic. Rhizome originally refers to a plant stem growing horizontally underground and sending out its roots and stems (Sutton 4). In Deleuze's meaning it is rather a notion that can be applied both for individual, thinking or understanding cultures, or even understanding world and life. In the introductory chapter to $A$ Thousand Plateuas (1980) Deleuze and Guattari stress the rhizomatic as opposed to the binary or causal relation between rather than cause-and-effect nature of occidental thought. Thus applying rhizomatic approach to thinking, the metaphor of the rhizomatic structure bellow a tree can be easily extended to the tree in the context of the whole forest (Sutton 4); thereby the rhizome "has neither beginning nor end, but always a middle (milieu) from which it grows and which it overspills" (Deleuze and Guattari, A Thousand Plateaus 21), thus regarding thinking much more complex. Therefore one may consider Deleuze's thought and philosophy to rhizomatic. Rhizomatic understanding of performance art manifests denial of the binary opposition between life and art, and enables far more plausible confluence between the two.

\subsection{Deterritorialization}

The rhizome and the metaphor may also appear useful when dealing with the notion of deterritorialization. Whenever we explore a thought (for the sake of this analysis it is Deleuzian) in the rhizomatic way, it has a potential, of ambiguous possibility, to produce a great change to the system. For such a change Deleuze coins a term deterritorialization (likewise in A Thousand Plateaus). This process of change, inevitably, is accompanied by a natural force that "attempts to the recreate stability and order, to reterritorialize" (Sutton 6 , emphasis in original). If we revisit the metaphor of the forest, we may imagine a force of new trees to naturally using sprouts and natural reseeding to deterritorrialize, wherefore the forest thus complements the shift but organic and slow process of reterritorialization. This very metaphor proves essentially powerful when considering all vanguard trends in modern art, where the avant-garde simply deterritorializes the order only to be later snatched by the terminology of academia, critics and the overall art milieu. As will be exemplified further, the levels of deterritorialization may vary, and can prove extremely effective when considering performance pieces where the boundaries 
between art and life as if to blur. In rendering seemingly undesignatable borderline between art and life, another crucial aspect of Deleuzian philosophy appears to be highly advocating: the notion of becoming.

\subsection{Becoming}

Speaking of deterritorialization, the issue of becoming minoritarian inevitably appears. Becoming, treated chiefly in A Thousand Plateaus as well as AntiOedipus, highlights "being" rather than to "be" of the Deleuze's philosophy, in other words, the fluid nature of one's identity. As Sutton argues, becoming is the result of constant movement of identity, which leads to the creation of the rhizome. "To appreciate becoming as a fact of life, a stage of critical self-awareness, or even an ethical response is to appreciate how identity itself is formed through opposition, alterity and difference" (46). As it seems, becoming as well as deterritorialization carry productive quality. In his introduction to Anti-Oedipus, Deleuze argues that the goal of (literary) machines is always to produce something (2). To put it differently - the process based nature of a machine is to be active. Deleuze further echoes D. H. Lawrence's "[w]e have pushed a process into a goal" and transverses the concept the idea that "the aim of any process is not the perpetuation of the process, but the completion thereof..." (Deleuze and Guattari, Anti-Oedipus 5). The process of a metamorphosis becomes its goal rather than the result - which is an ultimate task of performance art; Process-based performance art, as opposed to theatre, reasserts the reality, stresses the authenticity, nonimaginative character. Ideally theatrical hic et nunc conjoins the reality of the present moment. Deleuze also deploys the term.

\subsection{Haecceity}

To describe a process self-referrential understanding which manifests certain uniqueness, or in Deleuzian words, "thisness" (Deleuze and Guattari, AntiOedipus 7). As opposed to theatre, performance art highlights reality in the very moment, here and now. To translate to Deleuzian words, haecceity equals hereness and nowness of performance art. Haecceity not only manifests certain essence, uniqueness, particularity of oneself, but also the unrepeatability of (non-)theatrical hic et nunc. Later Deleuze develops haecceity in A Thousand Plateaus where the individuation process possibly merges with temporality par excellence: "haecceity has neither beginning nor end, origin nor destination; it is always in the middle. (like life). It is not made of points, only of lines. 
It is a rhizome" (263). It can be argued that it is haecceity, the "deformedly deformed" (253) which in fact through its endless specificity constitutes freedom.

\subsection{BwO}

In Anti-Oedipus, Deleuze goes as far as to pin down what is called Body without organs $(B w O)$ : "No mouth, no tongue, No teeth, no larynx. No esophagus. No belly. No anus" (8). As argued above, in his oeuvre, Deleuze likes to refer not only to objects but also to ideas as machines. Curiously, in Proust and Signs, Deleuze also touches upon performativity. To put it in a simple way, Deleuze designates idea as a sufficiently performative element: the performativity of thought: idea can be relevant as a fully independent art object. In concordance, Proust's essence is a superior viewpoint signifying the birth of the world and its originality. Thus "the work of art always constitutes and reconstitutes the beginning of the world, but also forms a specific world absolutely different from the others and envelops a landscape or immaterial site quite distinct from the site where we have grasped it" (I, 352; II, 249; HI, 895-96; qtd in Deleuze, Proust and Signs 110). Thus Deleuze addresses one of the most sensitive issues of artistic discourse: the limits of art (both in spatial and metaphysical level). In their treatment of the theatre of Antonin Artaud, Deleuze and Guattari operate with the notion of Body without Organs. To put it simply $\mathrm{BwO}$ manifests the potential(ity) of a virtual body of each physical body. In other words, it is our (body's) potential activated by the conjunction (or coexistence, cooperation) with other bodies - a relationship called becoming (see above o.3). Deleuze goes as far as to pin down so called full $\mathrm{BwO}-$ an ultimate zero point, or alternatively, as Deleueze argues later, Body without image (BwI), the imageless, non-productive, organless essence connected to the antiproduction (Deleuze and Guattari, Anti-Oedipus 8). In other context, this nothingness can the most famous work of John Cage, 4'33" or to the most controversial pieces of Tehching Hsieh, and Earth.

\section{Life-works of Tehching Hsieh}

In no way do we believe in a fine arts system; we believe in very diverse problems whose solutions are found in heterogeneous arts. To us, Art is a false concept...

Deleuze, Guattari3 
My view of life is: whatever you do, living is nothing but consuming time until you die. If the first two pieces are "working hard to waste time", the last two pieces are simply "wasting time". By choosing this approach, art is again going back to life itself. Hsieh"

In an interview with Adrian Heathfield, as a response to the question what he had done during the sixth and last performance, the thirteen-year plan, Tehching Hsieh (hereafter TH) answered that he tried to disappear (Heathfield 338). The disappearance or attempt to undo himself, or double disappearing, is an attempt of becoming somebody different, becoming nothing, becoming art. Unlike his previous oeuvre, the last piece of TH, Earth, which took full thirteen years to complete, intentionally omitted audience or spectators. The time stigmata of his first five durational pieces became an enigmatic echo in the last one. The disappearance of the author, so intensively obsessed with becoming Body without Organs (hereafter $\mathrm{BwO}$ ) in building art, in fact was a negation of those five pieces. Furthermore, what the piece \#5, _, inverted or deterritorialised, the last one re-inverted, re-deterritorialised.

The paper pays sufficient attention to the description of each works to both illustrate the unparalleled confluence of the artist's life and work in the course of the late $20^{\text {th }}$ century performing art, even the modern occidental art in general, 5 and to justify the aforementioned blurring of authorian life and work. In the course of modern art, primarily, it was Marcel Duchamp who stood up openly with the conceptualised appropriation of the Life Art binary connection rather than opposition:

If you wish, my art would be that of living: each second, each breath is a work which is inscribed nowhere, which is neither visual nor cerebral. It's a sort of constant euphoria. ${ }^{6}$

It is of no doubt, that Duchamp is rightfully considered to be a direct antecedent of what contemporary analysis considers modern art, conceptual art, or performance art. Furthermore, another influential developer of artlife connections in the performative milieu of the late 1950s is the artist and scholar Allen Kaprow, most remarkably in his introduction of the un-artness concept. According to Kaprow "[t]he un-artist [...] is the offspring of high artist who has left home" (230). In other words, the identity of the artist is contrasted to those of an ordinary living being by the realization, definition, aspiration, or framing; the latter being the most significant for the present 
paper. The identity of an un-artist permeates most notably the last two pieces of TH, the focal point of this paper. The idea of an artist in public, however, brings about the issues of framing (to be discussed later) and blurring of life and art, which Kaprow attributes with metaphoric charge:

Unless the identity (and thus the meaning) of what the artist does oscillates between ordinary, recognizable activity and the "resonance" of that activity in the larger human context, the activity itself reduces to conventional behaviour. Or if it is framed as art by a gallery, it reduces to conventional art. Thus tooth brushing, as we normally do it, offers no roads back to the real world either. But ordinary life performed as art/not art can charge the everyday with metaphoric power. (220)

Allan Kaprow, nevertheless, operates with the active participation of the audience, so called happenings. The social aspect of performance is in parallel ramified in the famous work The Presentation of Self in Everyday Life by Erving Goffman, wherein the notion of relationship between a performer and an audience is scrutinized.7 Additionally, Erving Goffman in his highly influential Frame Analysis (1974) explores the concept and implication of framing. For Goffman the frame is an organising principle for setting apart social events, especially those events that, like play or performance, take on a different relationship to normal life and normal responsibilities than the same or similar events would have as "untransformed reality" outside the confines of the frame (157). Such framing arrangements, as shall be illustrated further, play a seminal role in the oeuvre of $\mathrm{TH}$; most notably in the spatial and time context, rather than of those binary oppositions of a performer and the audience. Unlike in Goffman or Kaprow, the audience in TH's pieces is attributed less responsibility or active participation. The line between the artist and the spectator is designated clearly by the artist. Such artistic omnipotence is echoed by later theories, such as those of Nicholas Bourriard: to be an artist one has simply to be an artist (Sutton 78). One may argue that Bourriard's approach comprehension of artist matches so a complex identity of art/work nature of TH.

In the span of nearly three decades, exactly from the $3 \mathrm{O}^{\text {th }}$ September 1978 until $33^{\text {st }}$ December 1999 TH spent doing his artwork. ${ }^{8}$ All of his pieces share certain formal unities or framings, which are: each piece is announced beforehand by an official statement, signed by the author(s). To mark the beginning of each piece, $\mathrm{TH}$ shaved his head to illustrate the flow of time and 
let his hair grow freely for the duration. All works follow a strictly designated plan, in a strictly designated frame of time and place. In all works is mirrored the author's attempt to perform or dissolve his identity, as well as displacement. In his six works, the author's artist shifts from painting to performance where action becomes the frame.

\subsection{One year performance \#1: The Cage Piece}

For the first year Hsieh spent an entire year locked inside a cage that he had constructed in his loft. Without anyone to talk to, neither radio, nor television, nor books, he would stay only with himself - just being: thinking, counting the days. Each day, he documented on the ordeal by making a mark on the wall. An assistant, with whom he did not exchange words, brought him food, and disposed of his wastes. Additionally, each day TH would have himself photographed by the assistant.

\subsection{One year performance \#2: Punch Time Clock Piece}

In his second, arguably most famous piece Tehching punched a time clock every hour twenty four hours a day, for an entire year. Every time he punched the clock, a movie camera shot a single frame. The resulting time compresses each day into a second ( $24 \mathrm{fps}$ ), and the whole year into about a six-minute video.

\subsection{One year performance \#3: Outdoor Piece}

In this work, Hsieh stayed out of doors for a whole year. He did not enter any building or roofed structure. He spent the entire year roaming around Lower Manhattan in New York. He relied on pay phones and chance meetings to keep in touch with his friends. Each day, he recorded his wanderings on a map, noting in particular the places where he ate, slept, defecated, and how much money he spent.

\subsection{One year performance \#4: Rope Piece}

This performance was collaboration with Linda Montano, ${ }^{9}$ with whom TH spent a year tied together by an eight-foot rope. At the same time, they both tried to avoid touching each other, so that they could maintain some sense of personal freedom. Before the piece began, Hsieh and Montano had not known each other. But once it started they were never separated for the period of one year. Each day, they kept records of their time together by taking a photo and recording audiotapes. 


\subsection{One year performance \#5: $\square$ (will)}

In his last one-year piece, Hsieh just went in life. This last action in fact is a negation of the previous four. Hsieh spent an entire year without art: without making art, talking or reading about it, viewing it, or in any other way participating in it. Since there was nothing special during this period of his life, there was nothing to record.

\subsection{A 13-year plan: Earth}

This 13-year long piece about freedom is Hsieh's last performance: it lasted all the way from his thirty-seventh birthday to his fiftieth, on 31 December 2010. It was not documented, like the fifth performance, but it was followed by the documentation of his previous work in retrospect. When Hsieh announced the piece, he said he would make art, but only in secret: never to show it in public. He did not reveal the content or the purpose of the performance until the day the piece was completed. When the piece was over, the following day, on the 1 January 2000, TH produced a poster with a statement/picture which read: "I kept myself alive", and made it through to the new millennium. The last piece, ultimately secretive, appears to be the one most challenging in terms of interpretation. Therefore, the present paper attempts to present the thought of Deleuze and Guattari, most notably becoming and deterritorialization, as interpretative tools, since it appears that through deterritorialization $\mathrm{TH}$ was aiming to achieve what might be called becoming art.

\section{Becoming Art}

I really believe the future of art is not with the object, but between the artist and the public. [...] I really believe that performance is the highest form of art.

Abramović $^{10}$

You are a longitude and latitude, a set of speeds and slownesses between unformed particles, a set of nonsubjectified affects. You have the individuality of a day, a season, a year, a life...

Deleuze, Guattari ${ }^{11}$

In A Thousand Plateaus Deleuze and Guattari coin the term becoming to describe an operation of the social as well as personal identity. By becoming one 
represents the intersections of time and place, coordinates within social structures: longitude (materiality of our body) and latitude (genesis of our identity) (253). Identity here and now of becoming is thus an intriguing device when treating performance art. As already argued above, performance art, unlike theatre or drama, operates on reality. Similarly, Sutton observes "extraordinary potential" to contemporary performance art (72) either for the performer or participant as well as spectator. By ignoring spectator (important for Kaprow but not for Goffman as well as TH) we may come to a conclusion that haecceity, the intersection of the coordinates, the intersection between the particular time and place of the art as well as life, is not the intersection of personal identity and the identity of the others, but the intersection of tha author's (performer's) identity (life) and the work's duration (art). To put it differently the artists does not become $\mathrm{BwO}$ due to the presence of the spectator, but becomes art through the long-term intersection of his identity with his art.

The story of a 24-year-old refugee from Taiwan, coming to the USA as an immigrant, the story of $\mathrm{TH}$ is a story of becoming. These stories take place in a succession of deterritorialised and reterritorialised becomings. Each piece transforms or negates the previous one. As illustrated on the first piece, The Cage Piece, the author's isolation and solitude, self-denial, questions how much of outside nourishment can we give up to still remain ourselves? The purely existential gesture of the first piece limits the author to his mere being and accentuates the individual pursuit of identity. According to Deleuze, identity is always in motion; ${ }^{12}$ albeit static in space-bound, this piece manifests a dynamic haecceity of occidental and oriental thinking. Furthermore, taking into consideration the author's cultural background, Deluezian rhizomatic operation modes, as opposed to western binary oppositions, create a logical heterogeneous space in the loft of his New York studio. ${ }^{13}$ During this work, $\mathrm{TH}$ indeed designated spaces with the space, to enlarge the outer world. "I treated the corner with my bed as 'home' and the other three corners were 'outside'. I would take a walk 'outside' and then come 'home"' (327).

Active negation or performative inversion of the first piece marks the second one-year performance, the Punch Time Clock piece. Although spatially static, rather than space-bound phenomenon, the second piece explores adherence to the time and western culture, the alienation and blind attempt for symbiosis creating a nightmarish denial of one's own biological function. This work represents a manifestation of human acceptance of time. It accentuates deeper the issue of time and man's obsession with time. Stripping away all the contents 
and contexts away, Tehching struggles to experience something uniquely pure. He achieves this by pushing to an extreme the way our society equates time with work. The use of a time clock, the device that so mercilessly judges human accomplishment by the measure of time spent, marks the passage of time itself, devoid of any particular content, to become the sole object of his labours. By pushing our society's reification of time to its ultimate point, Hsieh was able to rediscover an inner experience of time, a sense of pure eventless duration. Additionally, the resulting film manifests the embodiment of time flow represented in a purely existential yet scientific manner. In Deleuzian terms, this piece indeed manifests author's becoming time by spatialising it. ${ }^{14}$

The Outdoor Piece, which Heathfield calls "Walking out of life", reflects the most vividly Hsieh's truly utopian approach to his work. Urban pilgrimage of his one-year struggle for passing time appears in NYC setting appears very desperate gesture and challenging task as well. Like both the preceding actions, the third piece is basically limited to the saturation of his basic needs. Hsieh's complete opening of himself up to the outside is a spatial inversion of his first action: the generous shift from internal to the external tested the author's survival abilities in circumstances that were more than usually beyond his own control. Deleuze and Guattari again provide sufficient material for critical treatment of this piece; like in all previous pieces, by deterritorialising from his previous oeuvre, the author becomes $\mathrm{BwO}$, pure substance allowing the passage of ideas. $\mathrm{BwO}$ with the potentiality and the desire to create structures and orders. As argued above, in this work, TH socially deterritorializes, cutting out of all social bonds, which he later recreates into so called the Rope Piece, makes him become homeless, literally. His isolation yet socialization lies both on the edge of existential (survival), artistic and social level.

The \#4 one-year performance, the Rope Piece explores the dimension of intimacy, and naturally, identity. How close can (two) people get and to what extent must they always remain strangers to one another? What are their identities/entities? Who am I /who are we? As Linda Montano says, she underwent the piece "not to waste a second. That art/life task shall become the task I have given myself until I die" - to make every minute count. ${ }^{15}$ In a letter to the author of this present paper, TH observed the Rope Piece also metaphorically portrays the umbilical cord visible. "When we die it ends. Until then we are all tied up. Being tied together is a very clear idea, because to survive we are all tied up together" ${ }^{16}$ From TH's overall oeuvre, this piece embodies social reterritorialization, but cultural deterritorialization. Binary 
oppositions of male-female, occidental-oriental, private-public, even art-life, come to the fore. ${ }^{17}$

In the last one-year performance together with his thirteen year piece TH proved his discipline; the will of Tehching reconfigured the relationship between art and life. The nature of both works lays a daunting question: how far can we go in art? Although both pieces appear contradictory, they share several important criteria: total absence of direct witnesses, primary preoccupation with art, unknown result. The previous four performances highlighted the pure duration, in case of the last two, the process remains enigmatic. Duchampean constant euphoria turns to un-art of Kaprow, most noticeable in case of the fifth piece, _, where TH manoeuvres on the border of what Agamben calls or negative presence. ${ }^{18}$ The negative presence or disappearing permeating both pieces suggests further inclination of the author towards more universal gestures. On the other hand, they might also manifest personal internalisation as well as social externalisation, that is apparent in the framing of all one-year performances as well as the thirteenyear plan. The year implies a full cycle of the Earth around the Sun, as well as a basic time unit in people's lives; the last piece marks the new millennium together with the author's $5 \mathrm{O}^{\text {th }}$ birthday.

Furthermore, Hsieh's pieces all suggest that through their repetition, and their absorption into daily routine, these tasks become as ordinary as anything else. And that is perhaps the most important transformation of all. The framing of Goffman and Kaprow becomes inverted and reterritorialised. From the occidental, or rhizomatic point of view, nevertheless, deterritorialised; becoming minoritarian is becoming majoritarian, no-art becomes art. Most notably in his last piece, Earth, TH truly put conceptual art into practice, elevated a thought to art, which is not a new concept, but adding the aspect of time, duration, longitude recreated original closure of his artistic oeuvre. The majority of people co-exist in last piece with Tehching. People create not showing it to the outside. From the minoritarian artistic elite, as well as his racial background, Hsieh has become majoritarian, became "white human". ${ }^{19}$

Becoming brings about dynamic power provoked by social operation of difference rather than physical or essential identity. As Deleuze and Guattari point out, "becoming is involutionary, involution is creative" (238). From the discussion above, it might be derived the connection between the presence of audience and certain spectacularity, whereas the absence of the spectator 
enables the working of true identity on the most fundamental level. As Stephen Zepke in his "Becoming a Citizen of the World: Deleuze Between Allan Kaprow and Adrian Piper" highlights, unlike performance, happening is the process of counter-actualisation. "Both Kaprow and Deleuze abandon the process of dramatization for an event of individuation, in which the score and its actualisation come to occupy a single plan(e) of composition coexistence with 'Life"' (qtd in Cull 112). Further, Zepke also develops the idea of coexistence of relationships. Happening is:

an individuation in which the actual and virtual dimensions, its plan(e) and the happening that occurs through and upon it, is a material composition defined by the differential relations to movement and the rest of the plan(e) establishes between its elements, and the affects that express and constructs the plan(e)'s becoming. (116)

Nevertheless, unlike happenings, the oeuvre of TH stands as individual testimonies regardless of its witnesses. Most notably the last two pieces, $\mathrm{TH}$ manifests literally what Deleuze calls becoming $\mathrm{BwO}$, hence he virtually disappears. Curiously enough, his last piece of TH, Earth, is on the other hand, what Deleuze and Guattari call a becoming secret (A Thousand Plateaus 288). Yet to what extent has the work achieved life quality?

Not only the last two pieces, but the whole oeuvre of TH manifests both an immense act of self-affirmation and self-erasure. Artistic creation of TH labours evidently does not produce - ultimately strenuous but ultimately empty and wasteful. In an attempt of conclusion, one may argue, the line between life and art is clearly designated by concept and framing: time, spatial, and above all, the one of thought. Ultimately, TH becomes machine, producing nothing.

\section{Becoming Art: Life}

My art certainly has a life quality. But I really don't blur art and life. The gap between each one year performance is life time.

Hsieh. $^{20}$

Art constantly provokes deterritorialisation, repeatedly. Blur with the artists life which constantly reterritorializes, can be translated into the following 
theorem: redeterritorialised efforts end up in dereteorritorialised ultimate state of blur.

As Deleuze acutely observes when dealing with the relationship between becoming and reality "[o]ngoing process of becoming is the becoming of reality" (Anti-Oedipus 35). Thus Deleuzian rendering of becoming may lead us to satisfactory observation that the dichotomy of life and art may not only be unbinarized, but applying rhizomatic thought of Deleuze on the art-life relationship, the former can successfully become the latter. From Goffman we learnt the importance of framing. Hence let us agree on the following theorem, taken into account the statement of TH of not blurring art and life:

\section{life-work $\rightarrow$ life-work}

Life and work become one, if one wants: the decision of Duchamp and affirmative consciousness of Baurriard. But can one become art? Or BwO? Or nothing as in the last pieces of TH? In A Thousand Plateaus, Deleuze and Guattari elaborate on nothingness (240). ${ }^{21}$ Nothingness as sheer potentiality, as can be illustrated on the work of John Cage, most particular his 4'33" which is a piece of music about silence, or better say a silent piece. (Deleuze and Guattari, A Thousand Plateaus (267), ${ }^{22}$ (269). ${ }^{23}$ According to Deleuze, music has the greatest potential of deterritorialization (300) ${ }^{24}$ Music, particularly John Cage, can be in Deleuzian words used as an example par excellence of how deterritorialization accentuates the happening. Silence, like nothingness, 4'33", or Earth are relative, since it is free of our (spectator, listener) activity. Such concept of seeming inactivity, BwI, nevertheless, is full of potential and deterritorialising force.

Deleuze and Guattari subtract (or abstract) the artistic intention; concept. The modulations are more important than the decisions, since they reveal the forces "that populate the world, that affect us, that make us become" (Sutton 75). Becoming serves as a conceptual art tool that proves useful when considering the life-works of TH, whose leitmotifs imply identity, time, life, and art. Identity, treated by Deleuze and Guattari once again, appear as always in motion, always coming into being, a never ending project of becoming; becoming as both a guiding principle for the analysis of culture, and an ethical call for a different way of being (or becoming). Thus the successive link of TH's performances embody a series of becomings: becoming $\mathrm{BwO}$, becoming secretor BwI respectively.

Another plausible reading of natural deterritorialization of TH's art in the 
context of western art canon is for his oriental identity. ${ }^{25} \mathrm{TH}$ creative acts seem inevitably both as deterritorialisations and reterritorialisations, because each successive plan of $\mathrm{TH}$ inverts or subverts the previous one. What is more, the closure of his 13 year old plan exposes, what arguable might be called re-deterritorialisation per se, i.e., ex post realization of his reterritorialised deterritorialisation, or laternatively, an ultimate deterritorialization, albeit temporal.

Rhizomatization of the relationship between art and life creates a satisfactory concluding moment for the last theorem to be pinned as regards the relationship between life and art. Framed art pieces conjoined with the duration of life create art life intersection in the duration, which, however, cannot last permanently.

$$
\text { Art }+ \text { Life-works }=>\text { Art Life }
$$

The self-denunciation and self-reflective anti-aesthetic drive of his work life accentuates the most important factor of his work which arguably is struggle for identity beyond limits. In this respect, Deleuze and Guattari supply a suitable pattern for reading works of contemporary performance, especially those on the verge of life-art. Goffman's framing is helpful in location of the designation between life and art. Finally, the artistic frame, or art frame, concept be it the one of un-art or work, grants security in life.

The only thing I'm sure about is that I'm still in the process of passing time, as I always am. Life becomes open and uncertain once again.

Hsieh. ${ }^{26}$

\section{Acknowledgements}

The research for this paper was generously granted and completed within the GAUK project 396211 supported by the Faculty of Arts, Charles University in Prague. 


\section{Notes}

1. Cf Heathfield, Adrian. Out of Now 330.

2. Qtd in A Thousand Plateaus 234.

3. A Thousand Plateaus 300.

4. Cf Heathfield, Adrian Out of Now 335 .

5. Identical turning of life into art as such might to certain be extent exemplified on the works and life, e.g., of Allan Kaprow, Gilbert and George, Marina Abramović, Annie Sprinkle, Orlan, Stelarc, or most notably on the prime example of outsider artists, Henry Darger. In case of all the aforementioned artists, however, certain limitations were restricted upon their life-like dimension of their work: in Darger's case it is the secrecy of his lifetime achievement, Annie Sprinkle attributed her life-art retrospectively, Orlan and Stelarc restrict only their bodies to being the tools for their art experiments, and finally for Abramović with Gilbert and George not was only a certain period of time. Tehching, although setting very strict boundaries to frame his works, extended his work basically to all his being for the period of more than 30 years.

Though the artistic endeavours of TH starting in the late 1970s and finishing exactly on the officially announced outbreak of new millennium, partly mirrored the period trends in the crisis of the self, there only a very few parallels in the Czech performance art of the period. The purifying and rejectionary gestures may be compared to Bliže k oblakum (Closer to the Clouds - 1977) and Sledování (Watching - 1972) of Karel Miler (quoted in Suk, 2003: 34), or Bez názzu (Untitled) by Jiří Kovanda, also from 1977.

6. Marcel Duchamp, quoted in Pierre Cabanne, Dialogues with Marcel Duchamp (New York: Da Capo Press, 1987, 196, 72).

7. Erving Goffman's emphasis upon the importance of audience is later developed by Dell Hymes into the notion of performance as a cultural behaviour for which a person assumes responsibility to an audience. See Dell Hymes, in Breakthrough into Performance, in Ben-Amos and Goldstein, Folklore, (New York and London: Routledge, 1969, 208.

8. In the early 1970 os before his arrival in USA, unaware of neither of the above mentioned period theories, nor Jackson Pollock, nor Yves Klein's Leap into the Void and Shoot of Chris Burden, TH starts with action painting and performs fump (1973), a self-destructive piece of jumping onto the concrete from the second floor ending up with both ankles broken.

9. Linda Montano had been a collaborator with Tom Marioni: before this work they had performed Handcuff - a piece when she was handcuffed with Marioni for the duration of three days.

10. Marina Abramović, cited in Heathfield, Adrian. Live: Art and Performance, 151.

11. "[...] (regardless of its duration) - a climate, a wind, a fog, a swarm, a pack (regardless of its regularity). Or at least you can have it, you can reach it" (Deleuze and Guattari, A Thousand Plateaus 262).

12. Unlike Bergson, who believes the identity is always in duration. See Henry Bergson, Time and Free Will; for up-to-date research accentuating Bergson and Deleuze in the context of performance milieu see also the research of Matthew Goulish, Laura Cull, Stephen Zepke or Éric Alliez. Alliez argues in favour Deleuzean reading of performance art, most notably highlights the shift "theatre" to the "factory", the shift from the dramatization of becoming by the social, to the production of becoming in the social (Éric Alliez 2003: 144 cf Zepke, 109, qtd in Cull, Laura, Deleuze and Performance. Edinburgh: Edinburgh 


\section{JAN SUK}

University Press, 2009). Éric Alliez explores the break form theatrical in the Deleuzean thought most particularly in his "The BwO Condition, or, The Politics of Sensation" in É. Alliez and E. von Samsonow (eds), Biographen des organlosen Körpers, Vienna: Turia+Kant. 2003. In his "Becoming a Citizen of the World: Deleuze Between Allan Kaprow and Adrian Piper" Stephen Zepke provides an original in-depth analysis of Allan Kaprow's happenings read through Deleuze, in Cull, Laura, Deleuze and Performance. Edinburgh: Edinburgh University Press, 2009.

13. Furhtermore, Delueze operates on the notion of racial determination of degrees of deviance in relation to the White-Man face (A Thousand Plateaus, 178) in other words, binarization of western identity/thought. In this aspect, $\mathrm{TH}$ ways of escapism is of a logical analogy deterritorialization of the given order, alterity, unsameness, divergence, or as Deleuze puts it, the issue of biunivocalization and binarization (179).

14. Delueze adjusted the notion of time by implementing that of Bergson: when we observe change, we usually do so by measuring the difference between a present and a past state. In effect, we measure time's passing we spatialise duration, creating "cut out-and keep" images that we can compare in order to conceive of change. We measure time by spatialising it. The change is inevitable; "The truth is that we change without ceasing" (Bergson, Creative Evolution, 2).

15. Quoted in Suk, Jan. "Tehching Hsieh: One-life Performance", 34.

16. Suk 35 .

17. For its thought-provoking nature, together with the Punch Time Clock Piece, this performance remains the most critically scrutinised, most notably by feminists, and sociologists.

18. Availability-toward-nothingness, although it is not yet work, is in some way a negative presence, a shadow of being-at-work: it is work, and as such constitutes the most urgent critical appeal that the artistic consciousness of our time has expressed toward the alienated essence of the work of art (my emphasis). See: Giorgo Agamben "Privation is Like a Face" in The Man Without Content (Stanford: Stanford University Press, 1994, 1999, 67. Cf Heathfiled, Adrian. Out of Time 55).

19. It is important not to confuse "minoritarian", as a becoming or process, with a "minority", as an aggregate or state. Jews, Gypsies, etc., may constitute minorities under certain conditions, but that in itself does not make them becomings. One reterritorializes, or allows oneself to be reterritorialised, on a minority as a state; but in a becoming, one is deterritorialised (Deleuze and Guattari, A Thousand Plateaus, 291). It is interesting to note that Deleuze and Guattari do not operate with the notion of becoming man; it is always becoming woman, becoming animal, becoming minoritarian, etc. (Ibid).

20. Cf Heathfiled, Adrian. Out of Now 334.

21. "Merging with nothingness is peaceful oblivion; but to be aware of existence and yet to know that one is no longer a definite being is distinguished from other beings". Mortaility, fragility [quotation from H.P. Lovecraft, "Through the Gates of the Silver Key", in The Dream-Quest of Unknown Kadath (New York: Ballantine Books, 1970, 191192)].

22. John Cage "deployed this fixed sound plane, which affirms a process against all structure and genesis, a floating time against pulsed time or tempo, experimentation against any kind of interpretation, and in which silence as sonorous rest also marks the absolute state of movement". 
23. As Cage says, it is of the nature of the plan(e) that it fail. "Where did the title of your second book, A Year From Monday, come from?" "From a plan a group of friends and I made to meet each other again in Mexico 'a year from next Monday'. We were together on a Saturday. And we were never able to fulfil that plan. It's a form of silence $[\ldots]$ The very fact that our plan failed, the fact we were unable to meet does not mean that everything failed. The plan wasn't a failure" [John Cage and Daniel Charles, For the Birds (Boston: Marion Boyers, 1981, 116-117)].

24 . The refrain is rather a means of preventing music, warding off, or forgoing it.

[...] Music submits the refrain this very special treatment of the diagonal or transversal, it uproots the refrain from its territoriality. Music is a creative, active operation that consists in deterritorializing the refrain. Whereas the refrain is essentially territorial, territorializing, or reterritorializing, music makes it a deterritorialized content for deterritorializing form of expression.

25. Deleuze operates on the notion of racial determination of degrees of deviance in relation to the White-Man face (A Thousand Plateaus 178) in other words, binarization of western identity/thought. In this aspect, $\mathrm{TH}$ ways of escapism is of a logical analogy deterritorialization of the given order, alterity, unsameness, divergence, or as Deleuze puts it, the issue of biunivocalization and binarization (179).

26. Heathfield, Adrian. Out of Now 341.

\section{Works Cited}

Agamben, Giorgo. "Privation is Like a Face" in The Man Without Content. Stanford: Stanford University Press, 1994, 1999.

Bergson, Henry. Creative Evolution. Dover: Dover Publications, 1998. Bourriard, Nicholas. Relational Aesthetics. Paris: Presses du Réel, 2002.

Cabanne, Pierre. Dialogues with Marcel Duchamp. 1969. New York: Da Capo Press, 1987.

Cull, Laura. Deleuze and Performance. Edinburgh: Edinburgh University Press, 2009 .

Deleuze, Gilles. Proust and Signs. 1973. Minneapolis: University of Minnesota Press, 2004.

---. The Logic of Sense. New York: Columbia University Press, 1990.

Deleuze, Gilles and Félix Guattari. A Thousand Plateaus: Capitalism and Schizophrenia. Minneapolis: University of Minnesota Press, 1987.

---. Anti-Oedipus. 1977. Cambridge: The MIT Press, 1992.

Sutton, Damian and David Martin-Jones. Deleuze Reframed, London: I.B. Taurus, 2008.

Goffman, Erving. Frame Analysis. New York: Doubleday, 1974.

---. The Presentation of Self in Everyday Life. New York: Anchor. 1959.

Heathfield, Adrian. Live: Art and Performance. London and New York: Routledge, 2004. 
JAN SUK

---. Out of Now. Cambridge: The MIT Press, 2008.

Hymes Dell. "Breakthrough into Performance." Folklore: Performance and Communication. Ed. Daniel Ben-Amos and Kenneth Goldstein. New York and London: Routledge, 1975 .

Kaprow, Allan. Essays on the Blurring of Art and Life. Berkeley: University of California Press, 2003.

Suk Jan. "Tehching Hsieh: One-life Performance." Umělec 3, 2003: 34-35. 